\title{
Migration and Adaptation of the Loksado Dayak Tribe (Historical Study of Dayak Loksado Community in Pelantingan Village)
}

\author{
Heri Susanto $^{1 *}$ Helmi Akmal ${ }^{2}$ Fathurrahman ${ }^{1}$ \\ ${ }^{1}$ History Education Department, Faculty of Teacher Training and Education, Lambung Mangkurat University, \\ Banjarmasin 70123, Indonesia \\ ${ }^{2}$ Social Studies Education, Postgraduate, Lambung Mangkurat University, Banjarmasin, Indonesia. \\ ${ }^{*}$ Corresponding author.Email: iniherisusanto@ulm.ac.id
}

\begin{abstract}
Migration that occurs in the Loksado Dayak community is a process of gradual migration that has occurred for more than a decade. The Loksado Dayak tribe lives by relying on forest products, the main forest products of which the Dayak people sell are rice, cinnamon, rubber, and candlenut. Historically, based on investigations of historians, it is explained that the relationship between the Dayak Loksado people in the mountainous area and the people located in the capital area, in this case the City of Kandangan, occurs because of economic interests. The desire to make ends meet has driven the Dayak Loksado people to travel to the center of civilization to sell the various agricultural products they get. The place where the Loksado Dayak tribe will stop by if they want to go to Kandangan is in Pelantingan Village. The adaptation process that occurs shows diffusion, acculturation and dialectic patterns. The diffusion pattern is indicated by the presence of cultural elements that are completely brought by the immigrants, in this case the Loksado Dayak people along with their migration to Pelantingan Village. The acculturation pattern is shown by the combination of two cultural elements, including in the aspects of the language used by the Dayak people in Pelantingan Village. While the dialectical pattern can be seen from how the process of religious conversion of the Loksado Dayak people in Pelantingan Village. The acculturation pattern is indicated by the combination of elements of two cultures, including in the aspects of the language used by the Dayak community in Pelantingan Village. While the dialectical pattern can be seen from how the process of religious conversion of the Loksado Dayak people in Pelantingan Village. The acculturation pattern is shown by the combination of two cultural elements, including in the aspects of the language used by the Dayak people in Pelantingan Village. While the dialectical pattern can be seen from how the process of religious conversion of the Loksado Dayak people in Pelantingan Village.
\end{abstract}

Keywords: Migration, adaptation, economy, socio-culture.

\section{INTRODUCTION}

The movement of population from one place to another has been going on since ancient times, migration movements were carried out in small or large groups, because in the past there were no administrative boundaries so at that time they were free to move or migrate [1].

In the beginning, humans lived from the grace of the natural surroundings. The population is still small, the environment provides enough foodstuffs in the form of fruits and animals that they can easily control with their limbs. They live on a cultural level as food collectors. Along with the size of the population, food needs are increasingly difficult to collect. The discovery of the use of tools that they were previously unfamiliar with, helped make it easier to collect more foodstuffs thus encouraging faster population growth, but eventually the environment was also depleted again which suppressed the increase in numbers. People are forced to move to other places, with the animals they have raised, looking for a better environment to support their livestock brought [2].

Clifford Jansen argues that until now there have been only a few attempts to formulate a general theory of migration, even though the phenomenon of migration itself is practically as old as human history [3]. In-depth investigations into the phenomenon of migration have shown that migration is a demographic problem, because migration affects the number of people in the area of origin and destination. It is an economic problem because most of the movement from one place to another is caused by an economic imbalance between the two regions. Migration is also a social psychological problem because individual problems, apart from playing an important role in the success of a person integrating into the host society they visit, also affect the decision-making process to move [4]. The Loksado Dayak tribe used to be known as one of the tribes whose people live in groups who live in the forests 
and hills of the interior of South Kalimantan. Their livelihoods are gathering, hunting, farming with shifting cultivation practices, and doing a little trade. All this is done by them with simple equipment and sufficient abilities [5]. The Loksado Dayak tribe lives by relying on forest products, the main forest products of which the Dayak people sell are rice, cinnamon, rubber, and candlenut. Meanwhile, the others only add to their belongings such as bananas, durian fruit, kapul fruit, cempedak fruit and bamboo trees. The forest products are exchanged for basic necessities and traded at the Kandangan market. Although the Dayak Loksado tribe live in forests and hills in the interior, it does not mean that they never leave their residential areas, through river transportation using lanting or rafts made of bamboo to Kandangan. This activity should be assumed to be the beginning of the migration and adaptation process of the Loksadi Dayak tribe to Pelantingan Village.

\section{METHOD}

This research is a historical research which aims to examine the migration and adaptation of the Loksado Dayak people in Pelantingan Village. In accordance with these objectives, this study uses historical research steps.

Data obtained from written and unwritten data sources. The sources of written data are archives, academic papers and statistics. Meanwhile, unwritten data were obtained through informants who were figures of the Loksado Dayak Community and other figures related to the theme of the study. Unwritten data were obtained by following the concept of historical oral assessment. The process of criticism is carried out on written data and unwritten data, in some parts criticism is also carried out by comparing the two data sources. In writing the research results, interpretation is carried out using various relevant social and cultural theories as a guide to the analysis of historical facts obtained.

\section{RESULT AND DISCUSSION}

\subsection{Factors of the Occurrence of Loksado Dayak Migration}

The Banjar people believe that the existence of the Loksado Dayak tribe, genetically, lived in Meratus more than the Banjar people, this is not an empirical event but a memory that the Dayak Loksado tribe believes to be true, a myth about the two brothers, Ayuh and Bambang Basiwara. The local Dayak tribes who live in Hulanuk, Panggungan, Lumpangi, Malinau, Tumingki, Kembali, Louklahung, Loksado, Hulu Banyu, Haratai, Kamawakan, and Hulu Banyu villages, are descended from Datu Ayuh and the Kandangan people are descended from Bambang Basiwara. The Loksado Dayak tribe thinks that the Loksado people and the Kandangan people have blood relations so that they are relatives.

Historically, based on investigations of historians, it is explained that the relationship between the Dayak Loksado people in the mountainous area and the people located in the capital area, in this case the City of Kandangan, occurs because of economic interests. The desire to make ends meet has driven the Dayak Loksado people to travel to the center of civilization to sell the various agricultural products they get.

The place where the Loksado Dayak tribe will stop by if they want to go to Kandangan is in Pelantingan Village. Pelatingan village used to be a stopover where the Loksado Dayak tribe stopped and put their palm trees before they went to Kandangan Market to sell forest products. In Pelantingan, at that time, only 7 houses were originally lived in Kandangan. As long as the Loksado Dayak tribe was in stopover to be precise at Pelantingan Village, in a long process of time they finally argued to settle in Pelantingan Village and mingle with the Kandangan people. With the settlement of the Loksado Dayak tribe in Pelantingan Village, naturally there was a process of interaction with the local population, namely Kandangan. the interaction between the Loksado Dayak Tribe and the Pelantingan people has made the Loksado Dayak Tribe influenced by the lifestyle of the Pelantingan community so that they are motivated to migrate to Pelantingan Village, Kandangan Village, Kec. Kandangan. The residence of the Loksado people in Pelantingan Village allows them to be close to the center of government such as the village office, sub-district office, district head office, and hospitals. Knowing the religion of Islam, education like schools, and living permanently in the village.

The Dayak Loksado tribe who moved to Pelantingan Village intentionally or unintentionally made adjustments by both parties, adapting to the Kandangan people following the customs and norms of the local population. The intensity of the Loksado residents who came to Pelantingan was accompanied by their settling in Pelantingan Village. In terms of quantity, the population of the Loksado Dayak tribe is increasing so that over time the Loksado people dominate the area in Pelantingan Village. The description above implies the phenomenon of the migration of the Loksado Dayak tribe to Pelantingan Village.

In particular, the factors causing the migration of the Loksado Dayak tribe to Pelantingan Village can be explained as follows:

\subsection{Migration factors}

Geographically, Loksado District is classified as hilly and is a river flow, with an altitude of about 200-1650 M above sea level. hilly area with steep slopes (between $25 \%$ to more than $40 \%$ ) in Loksado District covering an area of 15,180 hectares. This steep slope area is part of the Meratus mountain route which partially functions as a protected forest [6].

One of the challenges in life that humans experience is adjustment to the environment or the natural surroundings. The way humans respond to life without having to question the distance of migration, easy or difficult, every migration has a place of origin, destination, and various obstacles that impede. Such as the migration of the Loksado Dayak tribe to Pelantingan Village. There are several factors that can be seen as the cause of the migration of the Loksado Dayak tribe to Pelantingan Village. In every region there are many 
factors that influence people to settle in that place, and there are also other factors that cause them to leave that area.

The driving factors that cause the population to migrate, the reduced natural resources, the narrowing of jobs at the place of origin, due to the entry of technology that uses machines, the presence of pressure or discrimination in politics, religion, ethnicity, in the area of origin are no longer compatible with adat culture / beliefs in the area of origin, reasons for work or marriage that cause failure, personal career development, natural disasters, floods, dry season fires or disease outbreaks. These factors cannot be separated from the influencing factors such as economic, social, cultural and educational factors [7].

The most dominant factor influencing someone to migrate is the difficulty of obtaining income in the area of origin and the possibility of obtaining a better income in the destination area. Similar to Ravenstein's theory which states that economic motives are the main driving force for migration, the higher one's income, the higher the frequency of that person's mobility. Where there is an increase in per capita income, it will result in economic growth which in turn results in an increase in job opportunities [8].

The economic factors referred to here are economic factors related to the livelihoods of the Loksado Dayak Tribe. Most of the Dayak Loksado are farming. The life of the Loksado Dayak tribe is that they are farming with a shifting cultivation system, this shifting cultivation is due to their lack of knowledge in cultivating the land. In addition, there is an assumption that if the land or land has been used for agriculture, the nutrients contained in the soil are considered depleted.

Loksado Subdistrict consists of 11 villages located in the foothills of the mountains, its natural state is in the form of hilly high land, the more it slopes to the west. The soil is fertile with a tropical climate with rainfall between 2000 $3000 \mathrm{~mm}$ per year. Tropical forests that dominate the area consist of various types of trees such as lanan, meranti, ironwood, and others. In addition there are streams of rice fields, stretches of rubber, cinnamon, and other gardens. The lack of knowledge of the population in cultivating the land was good because around 1960-1980 this sub-district was still closed. Where to reach Loksado people still have to use footpaths and can only be traversed on foot, causing people's knowledge of agriculture to be left behind. The river is used as the main means of transportation to carry forest / field and garden products from the village to the capital, sub-district or district located in a lower area as a means of using lanting. To meet their basic needs, the Loksado Dayak tribe must sell their forest products to Kandangan Market, because if they are not sold to Kandangan Market they will not get money to buy their basic needs. The forest products that the Dayaks mainly sell are rice, cinnamon, rubber and candlenut. Meanwhile, the others only add to their belongings such as bananas, durian fruit, kapul fruit, cempedak fruit and bamboo trees. The forest products are sold to Kandangan Market, for land trips it is very difficult to reach because the distance traveled can reach 10 hours, so the Dayak Loksado tribe prefers the water transportation route, the distance is around 6 hours.
This resulted in the Loksado Dayak tribe having to spend the night at a stopover, namely in Pelantingan Village, before heading to Kandangan Market. The arrival of the Loksado Dayak tribe in Pelantingan Village was welcomed by the local community, the attitude of the Pelantingan people was very good and friendly even though the original population was Muslim while the Loksado Dayak tribe adheres to the Kaharingan religion, there is no difference between the natives and newcomers (migration) they respect each other and respect one another, so that there are family ties that are almost the same as local residents and immigrants. This is what makes the relationship between the two of them work well. The Loksado Dayak tribe usually gives a little money, along with the products that were not sold at Kandangan Market to the Pelantingan community as a thank you for being given permission to spend the night at their house. Difficult and the condition of the Loksado area from the capital made the Dayak people want to move to Pelantingan Village where by living in Pelantingan Village they were closer to selling forest products to Kandangan Market. Transfers also took place in order to find new livelihoods and hopes so that the economic situation would improve.

In 1980 the Loksado Dayak tribe, after selling agricultural and forest products, they had enough money, because according to one informant, their average income in 1 month, starting from Rp. 3,000,000 to Rp. 4,000,000 per month, so they can buy land in Pelatingan Village which costs Rp. 3,000,000 in one piece, so the Dayak Loksado Tribe earns 1 month to buy land, build housing in Pelantingan Village. Even though the data is still debatable, it is a definite historical fact, housing was built by the Loksado Dayak community along the banks of the Amandit river.

Another factor that influences the decision of the Loksado Dayak community to settle in Pelantingan Village is the factor of education. This factor can be identified as a result of the interaction between the Dayak Loksado community and the outside community, especially Kandangan which is more advanced in terms of education. Intensively, the interaction process has caused the Dayak Loksado community to yearn for the same progress as the Kandangan community, including in the field of education.

Based on interviews with Dayak community leaders in Pelantingan Village, it was found that some of the Dayak Loksado people at that time had the view that education had a very big influence on one's personal development. The outlook on life, the ideals of the nation, the socio-culture and the development of science will color the condition of the community. Society has an important role in achieving educational goals. The Loksado Dayak tribe has realized the importance of education for their children. Therefore, the Loksado Dayak Tribe who moved (migrated) to Pelantingan Village on average have sent their children from elementary school to university. In fact, many Loksado Dayak children have succeeded in becoming successful people. One of them was Mr. Hasan, he came to Kampung Pelantingan in 1981, to enter junior high school (SMP) in SMP Negeri Karang Jawa in 1984 Kec. Padang Batung, Hulu Sungai Selatan Regency [9]. 


\subsection{The factors that attract migration}

The first pull factor identified was job opportunities. Employment opportunities change from time to time, these changes mainly occur as a result of changes in the economy. Job opportunities contain the meaning of the amount of availability of production businesses to employ the labor needed in the production process, which can mean jobs or opportunities available for work that exist from one time in economic activity. Job opportunities can be created when there is a demand for labor in the labor market, so in other words job opportunities also show the demand for labor regardless of how much work each person has or the income that will be generated. Job opportunities change from time to time,

This is in accordance with the concept in economics that the demand for labor is a derived demand from society's demand for goods and services in the economy. If the economy develops, employment will also increase. Economic growth can have a positive impact on employment opportunities and labor productivity. The expansion of job opportunities is an effort to develop sectors for the storage of job opportunities with low productivity. Efforts to expand employment opportunities cannot be separated from factors such as growth in population and labor force, economic growth, levels of labor productivity, or policies regarding the expansion of employment opportunities itself [10]. This job opportunity is mainly related to employment opportunities in the trade sector. The Loksado Dayak tribe mostly relies on agricultural products and forest products.

It is known that after they are successful, and the income level of selling at Kandangan Market is more profitable. So more and more Loksado Dayak Tribe migrated to Pelantingan Village. By hoping to find a more decent job with a higher income, namely by migrating to the city to get a lot of income to meet their family's needs.

Another fact that has been identified as a pulling factor for this migration is the existence of kinship ties that are slowly forming between the Kandangan community in Pelantingan Village and the Loksado Dayak community. The migration process that occurs is not a large wave of displacement that occurs at once, but rather a gradual migration. Community members who had moved earlier succeeded in forging stronger relationships with the local communities they visited. This relationship, among others, is in the form of marriage between the Dayak Loksado community and the natives around Pelantingan Village.

During its development, more and more marriages between these communities occurred so that migration continued. This is because they have the assumption that with the marital status of being married or already widowed / widower, it means that they have family dependents so that kinship / kinship with loved ones in the area they visit. So that the kinship relationship between local residents and Dayak Loksado residents is getting closer. An example of a marriage between the Loksado Dayak tribe and the Pelantingan people is the marriage of a woman from Pelantingan Hamlet with a man from the Loksado Dayak Tribe. Furthermore, the man from the Dayak Loksado tribe who has succeeded economically, and has settled in Pelantingan Village, brought his family to live in the village, and his children could go to school.

Based on historical factswhat has been identified has an attraction for the Loksado Dayak tribe in Pelantingan Village because it is considered to be able to provide facilities and sources of livelihood for residents, both residents in the area itself and residents around it and other areas. The family ties and good relations between those who have succeeded in Pelantingan Village and the residents who have been left behind in the Loksado area are also special attractions for newcomers to Kampung Pelantingan. Information from Loksado residents who migrated to Pelantingan Village explained that they managed to build houses and dangang at Kandangan Market, making residents from their hometowns increasingly interested in migrating to Pelantingan Village. Usually, the Dayak Loksado tribe who successfully trades will attract relatives in their home village to increase family income, for example, the first thing to bring is their wife, children, and relatives. The Loksado Dayak tribe believes that by living in a city their children can get a proper education.

This condition is reinforced by the myth that lives among the Loksado Dayak tribe about the blood connection between the Loksado Dayak Tribe and the Banjar Hulu people. Both are believed to have originated from one family, passed down by two brothers named Ayuh and Bambang Siwara. Ayuh still chose to live in the mountainous area, from which the Bukit people were sent down, Bambang Siwara lived outside the mountainous area, then sent down the Banjar Hulu people. The belief in blood ties has made the Loksado Dayak people consider the Banjar Hulu people as brothers and call them dangsanak. So between the Dayak people and the Kandangan people there have been long ties of brotherhood.

\subsection{Adaptation of the Loksado Dayak Tribe in Pelantingan Village}

The process of diffusion of cultural elements is the result of, among other things, the migration of nations moving from one place to another on earth, the cultural elements they carry are also widespread. The spread of cultural elements can also occur without any movement of human groups or nations, but because these cultural elements are deliberately brought in by certain individuals [11].

Every individual to achieve their survival requires active adjustment to their environment both physically and socially. However, every individual in facing their environment always faces various challenges to overcome these challenges they must use their cultural knowledge. The community's response in facing the challenges of living in a new environment, limited work space in the area of origin causes community members to try to find work outside their area which is thought to provide an opportunity to continue their life [12]. Things like that were done, among others, by members of the Loksado Dayak community who migrated to Pelantingan Village.

The natural environment in the form of soil, climate, flora and fauna around humans are some of the reasons why 
community members in the past felt safe to occupy an area [13]. The harmony of human relations with the natural environment can be understood from the position of nature as a place to live and which gives human life. This means that nature is a source of livelihood for humans. For the Loksado Dayak tribe, adjustment to the new natural environment is very important, because nature can be said to be a place to live for them. Likewise with the Loksado Dayak Tribe who migrated to Pelantingan Village.

The natural conditions in Pelantingan Village, which used to be a lowland area and there is a flow of the Amandit river around the village, are not difficult for the Loksado Dayak Tribe, because the Loksado Dayak Tribe are also very dependent on the flow of the Amandit river, so they are not too difficult to adjust to the conditions of Pelantingan Village.

The Pelantingan community also plays an important role in adapting the Dayak Loksado Tribe to the natural conditions of Pelantingan Village. The manifestation of social adaptation strategies carried out by groups of migrants in the destination area, usually carrying out social interactions, such as visiting, making friends, chatting, engaging in road repair activities, ritual events, community crowd activities until finally manifested in marriage and the use of language everyday native people. This pattern depends on each situation faced by both individuals and groups [14].

Although they did not experience difficulties with the natural conditions in Pelantingan Village, the Loksado Dayak people had a little difficulty adjusting to the people of Pelantingan Village, because when the Loksado Dayak tribe came in 1980 to Pelantingan Village they embraced the Kaharingan religion, but starting in 1981 the Loksado Dayak tribe slowly embraced Islam, according to the beliefs of the people of Pelantingan Village.

The factor that causes the easy conversion of the kaharingan religion to Islam is because previously the Loksado Dayak tribe had known Islamic elements in various social lives of their people in their home areas, for example in trading activities. In the Muslim community in South Kalimantan in general, the buying and selling process usually ends with the pronunciation of the contract, which means that the buying and selling process between the seller and the buyer mutually agree. The words or contracts are "exchange" and "sell", "exchange" is usually mentioned by the buyer, while "selling" is mentioned by the seller. In the Loksado Dayak tribe, the contract process is also visible. However, just a different mention but the meaning is the same. The mention of the contract is "what do I sell" and "what do I exchange". "What do I sell" is mentioned by the seller, while "what I exchange" is mentioned by the buyer. If the contract has not been stated, either the seller or the buyer may cancel the transaction.

The tradition of the contract in buying and selling is according to the narrative of the Dayak Loksado community leaders in Pelantingan Village who contributed to giving confidence among the Loksado Dayak Community at that time that Islamic teachings were basically in accordance with the habits they had understood. This cultural dialogical process gradually gave the Dayak Loksado an understanding that becoming Islam was not the wrong choice. In other words, this cultural dialogue process has strengthened positive perceptions in society [15].

Another form of adaptation that occurs is the mixing of dialects in the Loksado Dayak people with Pelantingan residents in the use of the Banjar language, this is due to the intensity of the interactions that are quite often carried out by fellow residents. In addition, there was a mixed marriage between the Pelantingan Orang Pelantingan and the Loksado Dayak Tribe which also added to the mix between local residents and migrants. The use of the banjar language only uses the Dayak Loksado accent that is often heard.

Culture is always changing, because culture is a history of humans who are constantly giving new forms to existing patterns. Cultural change can occur internally or externally. Internal changes can be caused, among others, due to dissatisfaction with the prevailing order and regulations, the presence of inventors and innovators. External changes are usually more pronounced as a result or impact [16].

Cultural aspects change over time according to two patterns, namely the cultural acceleration and the logistical rush. In a cultural acceleration, the human ability to control his environment has increased by a rapid rate and the rate of acceleration itself is accelerating. In contrast, logistical rush refers to changes that start slowly, suddenly start quickly, then return slowly or stop altogether. There are various patterns of change that are very important, including patterns of evolution, diffusion and acculturation, dialectical patterns, and contemporary patterns of industrialization and modernization [17].

In this study the process of change that occurs shows diffusion, acculturation and dialectic patterns. The diffusion pattern is indicated by the presence of cultural elements that are completely brought by the immigrants, in this case the Loksado Dayak people along with their migration to Pelantingan Village. The acculturation pattern is indicated by the combination of two cultural elements, including in the aspects of the language used by the Dayak community in Pelantingan Village as previously described. While the dialectical pattern can be seen from how the process of religious conversion of the Loksado Dayak people in Pelantingan Village. The process of transferring belief began with the interaction of the two cultures which gradually influenced the thinking and action processes of the Loksado Dayak community in Pelantingan Village.

\section{CONCLUSION}

The results showed that the migration carried out by the Loksado Dayak tribe to Pelatingan Village took place from 1980 to 1995 . The occurrence of this migration was influenced by both push and pull factors. The driving factors for the migration of the Loksado Dayak tribe to Pelantingan Village were economic and educational factors. These two driving factors are a series that are interrelated, on the one hand the economic factor is the main factor that can encourage the migration of the Loksado Dayak tribe to Pelantingan Village.

The pull factor of the Loksado Dayak tribe migration to Pelantingan Village is the factor of job opportunities and the existence of family relationships. This job opportunity is 
because the income from trading is greater than farming and relying on forest products. Kinship relations are an equally important factor, because the Loksado Dayak tribe, which has been successful in trading, invited their children and siblings to migrate to Pelantingan Village.

The adaptation of the Dayak Loksado Tribe to the natural conditions in Pelantingan Village, which was once a lowland area and there was a flow of the Amandit river around the village, did not make it difficult for the Loksado Dayak Tribe, because the Loksado Dayak Tribe was also very dependent on the flow of the Amandit river. Socially constraints in adjusting to the people of Kampung Pelantingan, because when the Loksado Dayak tribe came to Pelantingan Village in 1980 they embraced the Kaharingan religion, but since 1981 slowly the Dayak Loksado people have embraced Islam, according to the beliefs of the people of Pelantingan Village. The process of change that occurs shows diffusion, acculturation and dialectic patterns.

\section{REFERENCES}

[1] RH Prawiro, Population Theory, Facts and Problems. Bandung: PT. ALUMNI, 1979.

[2] M. Azmi, S. Marfuah, and H. Susanto, "Learning Food Security from Original Tribe in Borneo", PROCEEDING ICTESS (International Conf. Technol. Educ. Soc. Sci., Vol. 1, no. 1, pp. 291-297, 2017.

[3] C. Jansen, Some Sociological Aspects of Migration. Yogyakarta: UGM Population Research Center, 1980.

[4] H. Susanto, "Social-Economic Dynamics of Transmigrants in Kambitin I Village, Haruai District, Tabalong Regency 1984-1991", Wiramartas, vol. 12, no. 1, pp. 1-11, 2012.

[5] H. Salim, Meratus Dayak Community, Official Religion and Emancipation. Yogyakarta: Borneo Study and Development Center, 2001.

[6] Bappeda of Hulu Sungai Selatan District, Loksado in Figures 2000. Loksado: Central Bureau of Statistics of Hulu Sungai Selatan Regency, 2000.
[7] ES Lee, Migration Theory. Yogyakarta: UGM Population Research Center, 1991.

[8] AW Puspitasari, Analysis of Factors Affecting Interest in Circular Migration to Semarang Regency. Diponegoro: Faculty of Economics, Diponegoro University, 2010.

[9] Hasan, "Loksado Dayak Community Education," 2012.

[10] LS Badriah, "ANALYSIS OF EXISTING CONDITION DEMAND AND LABOR SUPPLY IN INDONESIA," Sustain. Compet. Advant., Vol. 5, no. 1, pp. 78-91, 2015.

[11] Koentjaraningrat, Introduction to Anthropology. Jakarta: Rineka Cipta, 1990

[12] D. Budisantoso, Adaptation of Seasonal Migration to Living Environment (Special Capital Region of Greater Jakarta). Jakarta: Ministry of Education and Culture, 1990.

[13] H. Susanto, "Cross-Indigous Social Studies Learning in Teaching Multiculturalism Values Through Understanding Local Wisdom." pp. 335351, 2015.

[14] Suryani, "Loksado Dayak Community Education," 2012.

[15] H. Susanto, "Perception on Cultural Diversity and Multiculturalism Education," 1st Int. Conf. Soc. Sci. Educ. Multicult. Transform. Educ. Social Sci. Wetl. Environ. (ICSSE 20017), vol. 147, no. Icsse 2017, pp. 125-129, 2017, doi: 10.2991 / icsse-17.2018.30.

[16] Moeliono L., Changes in the Original Religious System of the Ekari Nation due to the influence of Catholicism in Enarotali. A Study Regarding Cultural Change in the Ekari ethnic group in Enarotali, Paniai-Irian Jaya Regency. Bandung: Faculty of Social and Political Sciences, Padjadjaran University, 1986.

[17] RH Lauer, Perspectives on Social Change. Jakarta: Rineka Cipta, 2001. 